\title{
Socio-psychological climate as a factor of competitiveness
}

\author{
A.A. Kurus, I.V. Bogdashev \\ Kuban State University \\ 149 Stavropolskaya St., Krasnodar, 350040, Russian Federation
}

\begin{abstract}
In this article the influence of the socio-psychological climate on the competitiveness of organizations is studied. Organizational atmosphere is considered as the main factor stimulating the growth of employees' productivity. The aim of this study is to analyze the competitive enterprises of the brewing industry on the Russian market, their financial performance and the organizational climate that prevails in the organizations, as well as to identify the interdependencies between these indicators. To analyse the psychological climate of the team such indicators as "salary rate", "management", "state of working place", "relation in collective", "career opportunities" and "job satisfaction" were used. "Profit", "net profit" and "revenue" of the companies were used for financial activity analysis. As a result of the analysis, a positive correlation between the presented indicators was revealed, which explains the interrelation of the financial performance of the companies and the organizational climate in them.
\end{abstract}

Keywords: socio-psychological climate, human resources, job satisfaction, competitiveness, identification of employees

\section{Introduction}

The organization is not isolated from society and, consequently, the socio-psychological climate depends firstly on the socio-political and economic situation in the state and, secondly, on the position of the industry in the national economy, as well as on the conditions and standard of living in the region where it is located.

Formation of a favorable psychological climate of the work is one of the most important conditions for the growth of productivity and quality of products. However, psychological climate is an indicator of development of team's social climate. This is associated with the prospect of increasing the social factors in the structure of production and improvement of both the organization and working conditions. The general social and ideological atmosphere in the country depends on the level of psychological climate of each individual.

The effectiveness of joint action depends largely on the optimal realization of personal and group capabilities. Favorable atmosphere in a group does not only affect its productive results but also creates a new opportunities and shows people' potential. That's why it is so important to study psychological climate due to the fact that it is a possibility to be reflected in a company's activity. 


\section{Literature Review}

The internal state of the organization is determined by a system of interrelated and dependent characteristics. Such characteristics are the compatibility of employees, the optimal leadership style, cooperation within and outside the organization, values, norms of behavior and attitude, the level of identification of individuals and groups with the organization as well as working conditions in the company and employees' job satisfaction. It is very important to form a favorable socio-psychological climate characterized by cooperation of workers, mutual assistance and absence of destructive conflicts in order to increase the competitiveness of the organization (Zhdanov, 2012).

Competitiveness is primarily a socio-psychological phenomenon. The strength of organization is in human resources. Human resources and all social and psychological phenomena that take place in the course of their joint activities lead to increasing the competitiveness of the organization. The approach, in which human resources are considered to be crucial in the process of increasing the competitiveness of the organization, pays significant attention of socio-psychological factors (Makarenko, 2011).

According to the article 163 of the Labor Code of Russia (Labor Code of the Russian Federation, 2018) the employer must create optimal conditions for the employee to fulfill all the norms of production. These conditions include such working conditions that meet the requirements of safety of production and labor protection. Improving working conditions for employees is an objective that employers should seek after. We can distinguish 4 groups of factors, affecting the formation and change of working conditions.

The first group includes social and economic factors, the effect of which determines the situation of workers in society. This group includes factors that characterize the attitude of the society to the sphere of labor activity in an organization and working conditions, complex of interests and value orientations of employees, characteristics of the staff, the style of leadership, etc.

The second group of factors is the technical and organizational factors directly affecting the formation of material elements of working conditions: such as the means of labor, the objects of labor, technological processes, organizational forms of production, labor and management, in particular, the modes of work and rest, the forms of division and cooperation of labor, methods of work, rationing of labor, etc.

The third group includes natural factors that characterize the impact of geographic, climatic, geological and biological features of the terrain, where the labor process is taking place, on workers.

The fourth group of factors is economic and household, associated with the organization of food workers, their sanitary and domestic services (Chechina, 2009).

In circumstances of a large number of individual private enterprises and a wide range of working places in the most popular sphere of marketing, goods production, service provision and so forth, every employer tries to create and improve such an organization atmosphere which will distinguish their company from others and be attractive for employees to become a part of it. That is why working conditions are indissolubly connected with the psychological climate.

Employers understand that both physical and psychological state of health of an employee will depend on working conditions. The better the working conditions are, the 
better the state of the employee is and, consequently, the higher his efficiency and productivity are. Remembering this rule allows a company to get more finished products at the output. The organization must maintain working conditions at an acceptable level and also improve them in order to obtain greater benefits from employees and create a comfortable environment for productive and qualitative results.

\section{Influence of organizational climate on competitiveness: practical example}

Now we are going to study Russian beer industry and describe working condition as well as financial indicators of three beer companies to make a competitive analyze and prove the hypothesis about interrelation of socio-psychological climate and companies' performance.

1. The Ochakovo Company is the largest entity of a beer and soft drinks industry of Russia without participation of the foreign equity. Ochakovo is included into the six of the leading brewing holdings of Russia, holds leading positions in the market of natural kvass and low alcohol cocktails. 22 entities are a part of the company: beer and soft drinks productions, winery, malting complexes and agricultural enterprises (Official site of Ochakovo Company).

2. Baltika is the largest Russian brewing company which is the leader of the Russian beer market with a share of $41 \%$. Baltika brand is one of two Russian brands on the list of the 100 largest world trademarks, compiled in April 2007 by the British newspaper Financial Times (Vinogradova, 2007). Based on the results of a similar rating compiled in April 2009, Baltika didn't get into the top 100 brands. The Baltika trademark has become one of the three leaders in the rating of the international brand-consulting agency Interbrand, as one of the most expensive brands (Official site of Baltika Company).

3. CJSC "Moscow brewing company" is a Russian company engaged in the production and sale of beer, low-alcohol and non-alcoholic beverages. It has entered the Russian market of drinks with products of own and licensed production in September 2008 (Official site of Moscow brewing company). The company includes a brewery, distribution and logistics centers located in Mytishchi, the Moscow Region.

The results of analysis are presented in table 1 .

Table 1

Competitiveness model of Ochakovo, Baltika and Moscow brewing company for 2017

\begin{tabular}{|l|c|c|c|}
\hline \multicolumn{1}{|c|}{ Working conditions } & Ochakovo & Baltika & Moscow brewing company \\
\hline Salary rate & 3.1 & 3.3 & 2.5 \\
\hline Management & 2.4 & 2.1 & 2.2 \\
\hline State of working place & 3 & 2.9 & 2.9 \\
\hline Relation in collective & 2.8 & 2.7 & 2.2 \\
\hline Career opportunities & 2.2 & 2 & 2.4 \\
\hline Employees' job satisfaction & 2.7 & 2.6 & 2.4 \\
\hline
\end{tabular}

Source: http://otrude.net 
As you can see the ratings of Russian beer industry is not great and should be improved to deserve a better recognition by people. In spite this fact, it is obvious that Ochakovo and Baltika got the highest indicators in all indicators that characterizes it as the best beer Companies to work for while Moscow brewing company get the lowest one and fell behind greatly from other two companies. Now we are going to analyze financial results in table 2 .

Table 2

Financial indicators of Ochakovo, Baltika and Moscow brewing company for 2017

\begin{tabular}{|l|l|l|l|}
\hline \multicolumn{1}{|c|}{ Indicators } & \multicolumn{1}{c|}{ Ochakovo } & \multicolumn{1}{c|}{ Baltika } & \multicolumn{1}{c|}{ Moscow brewing company } \\
\hline Profit & 7514083 & 86608441 & 35122648 \\
\hline Net Profit & 400434 & 12030946 & -1366434 \\
\hline Revenue & 692032 & 14256198 & 3472746 \\
\hline
\end{tabular}

Source: Financial reports taken from the companies' official websites.

\section{Results}

After studying the results, we have noticed that the company with the lowest sociopsychological climate, according to assessment of employees, has the poorest numbers of financial indicators. Baltika has got the biggest number that can be explained by the fact that it is the only Russian beer company on the international market. Speaking about Ochakovo, we can notice that it takes rather high position among other domestic beer companies in Russia and provides good working conditions for its employees that may lead to expansion of its share on the Russian beer market as well as its entering to the international arena.

\section{Conclusion}

As a conclusion it is important to say that formation of a favorable psychological climate of the work is one of the most important conditions for the growth of productivity and quality of products. However, psychological climate is an indicator of development of team's social climate. This is associated with the prospect of increasing the social factors in the structure of production and improvement of both the organization and working conditions. The general social and ideological atmosphere in the country depends on the level of psychological climate of each individual.

The effectiveness of joint action depends largely on the optimal realization of personal and group capabilities. Favorable atmosphere in a group does not only affect its productive results but also creates a new opportunities and shows people' potential. That's why it is so important to study psychological climate due to the fact that it is a possibility to be reflected in a company's activity.

(C) Kurus A.A., Bogdashev I.V., 2018

This work is licensed under a Creative Commons Attribution 4.0 International License 


\title{
References
}

Chechina O.S. (2009). Osnovy Upravleniya Personalom: uchebnoe posobie. Samara. (In Russ.)

Data for Competitive Model. Available at: https://otrude.net/employers/41537; Available at: https:// otrude.net/employers/25943; Available at: https://otrude.net/employers/39504 (accessed: 18.04.2017).

Labor Code of the Russian Federation. Available at: http://www.tkodeksrf.ru/ch-3/rzd-6/gl-22/st-163tk-rf (accessed: 25.03.2018).

Makarenko A.S. (2011). Pedagogicheskaya poema. Moscow, 311. (In Russ.)

The official website of Baltika Company. Available at: http://corporate.baltika.ru (accessed: 15.04.2017).

The official website of Moscow Brewing Company (accessed: 14.04.2017).

The official website of Ochakovo Company. Available at: http://ochakovo.ru (accessed: 14.04.2017).

Vinogradova E., Tutushkin A., Koryukin K. Cena brenda. Available at: https://www.vedomosti.ru/ newspaper/articles/2007/04/23/cena-brenda (accessed: 15.04.2017).

Zhdanov O.I. (2012). Socio-psychologichesky climat v collective. Personnel Management, 512 (In Russ.)

Article history:

Received: 26 March 2018

Revised: 20 June 2018

Accepted: 26 August 2018

For citation:

Kurus A.A., Bogdashev I.V. (2018). Socio-psychological climate as a factor of competitiveness. RUDN Journal of Economics, 26(3), 360-365. DOI: 10.22363/2313-2329-2018-26-3-360-365

\section{Bio Note:}

Kurus A.A., Master's Student of Economics and Management, Kuban State University. Contact information: e-mail: A.A.Kurus@mail.ru

Bogdashev I.V., PhD in Economics, Associate Professor, Theoretical Economics Department, Kuban State University. Contact information: e-mail: ilbogdashev@gmail.com

\section{Социально-психологический климат организации как фактор конкурентоспособности}

\author{
А.А. Курусь, И.В. Богдашев \\ Кубанский государственный университет \\ Российская Федерация, 350040, Краснодар, ул. Ставропольская, 149
}

В статье рассматривается влияние социально-психологического климата на конкурентоспособность организаций. Атмосфера в организации представлена как основной фактор, стимулирующий рост продуктивности сотрудников. Целью исследования является анализ конкурентных предприятий пивоваренной индустрии на российском рынке, их финансовой деятельности, а также организационного климата, который царит в организациях, и выявление 
взаимозависимостей между упомянутыми показателями. Чтобы проанализировать психологический климат коллектива были использованы такие показатели, как уровень зарплаты, управление организацией, состояние рабочего места, отношения с коллективом, возможности карьерного роста и удовлетворенность работой. Для анализа финансовой активности рассматривались показатели прибыли, чистой прибыли и доходов компаний. В результате анализа была выявлена прямая зависимость между представленными индикаторами, что объясняет наличие взаимосвязи финансовых показателей компаний и организационного климата.

Ключевые слова: социально-психологический климат, человеческие ресурсы, удовлетворенность работой, конкурентоспособность, идентификация сотрудников

\section{История статьи:}

Дата поступления в редакцию: 26 марта 2018

Дата проверки: 20 июня 2018

Дата принятия к печати: 26 августа 2018

\section{Для цитирования:}

Курусь А.А., Богдашев И.В. Социально-психологический климат организации как фактор конкурентоспособности // Вестник Российского университета дружбы народов. Серия: Экономика. 2018. Т. 26. № 3. С. 360-365. DOI: 10.22363/2313-2329-2018-26-3-360-365

\section{Сведения об авторах:}

Курусь Анастасия Александровна, магистр экономики и менеджмента Кубанского государственного университета. Контактная информация: e-mail: A.A.Kurus@mail.ru

Богдашев Илья Владимирович, кандидат экономических наук, доцент, доцент кафедры теоретической экономики экономического факультета Кубанского государственного университета. Контактная информация: e-mail: ilbogdashev@gmail.com 